быстрой оценки ситуации на рынке, быстрого принятия решений и внедрения изменений, непрерывного повышения квалификации кадров.

Таким образом, понятие «конкурентоспособность» можно рассматривать с различных позиций. С одной стороны, конкурентоспособность - это свойство объекта, характеризующее степень удовлетворения конкретной потребности по сравнению с лучшими аналогичными объектами, представленными на данном рынке. С другой стороны, конкурентоспособность - это способность объекта выдерживать конкуренцию в сравнении с аналогичными объектами в условиях конкретного рынка.

Исходя из представленных подходов, можно определить банковскую конкурентоспособность как интегральную характеристику, отражающую потенциальные и реальные возможности банка создавать и продвигать на рынок конкурентоспособные продукты и услуги, отвечающие всем требованиям клиентов, занимать и удерживать устойчивые позиции на рынке банковских услуг. В отличие от дефиниций, имеющихся в экономической литературе, данное определение отражает сложную природу рассматриваемой категории во взаимосвязи ее ключевых аспектов, характеризующих производимые банком услуги, его место на рынке банковских услуг, возможности банка по удержанию позиций на этом рынке.

$$
* * *
$$

1. Алифанов Е.Н., Кочмола К. В. и др. Финан $с$ совая глобализация и развитие банковской системы России: монография / под ред. К. В. Кочмолы. Рос-тов-на-Дону: РГЭУ 2003. С. 218.

2. Банковское дело / под ред. Г. Г. Коробовой. М.: Экономистъ. 2006. С. 53-104, 601-605.

3. Лутошкина Н. К. Банковская конкуренция и конкурентоспособность: сущность, понятие,

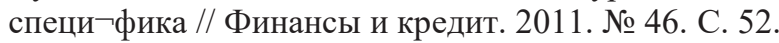

4. Самсонова Е. К. Формирование и развитие конкурентной среды на рынке банковских услуг России: проблемы и перспективы // Финансы и кредит. 2007. № 29. С. 73-76.

5. Тавсиев А. М, Ребельский Н. М. Конкуренция в банковском секторе России: учеб. пособ. для вузов / под. ред. А. М. Тавсиева. М.: ЮНИТИ-ДАНА. 2001. С. 52.

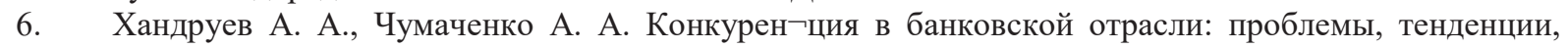
прогнозы // Банковсое дело. 2010. № 11. С. 7.

\title{
Измалкова И.В., Павлова А.И. \\ Бухгалтерские риски в деятельности предприятия: сущность, методы, оценки и пути их снижения
}

Липеиякии филиал Финансового университета при Правительстве РФ

doi: 10.18411/lj-04-2021-89

(Россия, Липеик)

\section{Аннотация}

В данной статье дана характеристика основных видов бухгалтерских рисков для формирования комплекса мероприятий по минимизации и управлению риском.

Ключевые слова: бухгалтерский учёт, конкуренция, бухгалтерский риск, финансовая отчётность, классификация рисков.

\section{Abstract}

This article describes the main types of accounting risks for the formation of a set of measures to minimize and manage risk.

Keywords: accounting, competition, accounting risk, financial reporting, risk classification.

За последнее десятилетие воздействие бухгалтерского учета на экономику развитых государств начало важно возрастать. Высококачественное внедрение (В.В., Риски в бухгалтерском учёте, 2018) бухгалтерского учета позитивно воздействует не только на финансовой защищенности организации или же государства в целом, но и на 
финансовой безопасности мировой экономики. Впрочем бухгалтерские риски ещё всецело не исследованы.

Можно отметить главные аспекты понимания риска с учетом воззрений всевозможных авторов, такого как И. Ф. Шерр:

- наступит или же не наступит событие;

- несение утрат и убытков;

- недостижение установленной цели;

- надежда на получение конкретных результатов;

- неопределенность хозяйственной деятельности.

Bсе перечисленные выше подходы, без сомнения, обоснованы и внятно описывают категорию «риск».

Можно дать следующее определение риску: «Риск - это черта процесса выбора меж воздействием и бездействием или другим действием, сопряженного с возможностью оказаться в худшем положении, как итогом выбора».

Это определение является наиболее универсальным, потому что именно финансовый результат характеризует итоги развития предприятие и любой негативный факт так или иначе отражается в валютном выражении на финансовом результате.

Бухгалтерскому риску присущи определенные качества. Рассмотрим их на рис.1.

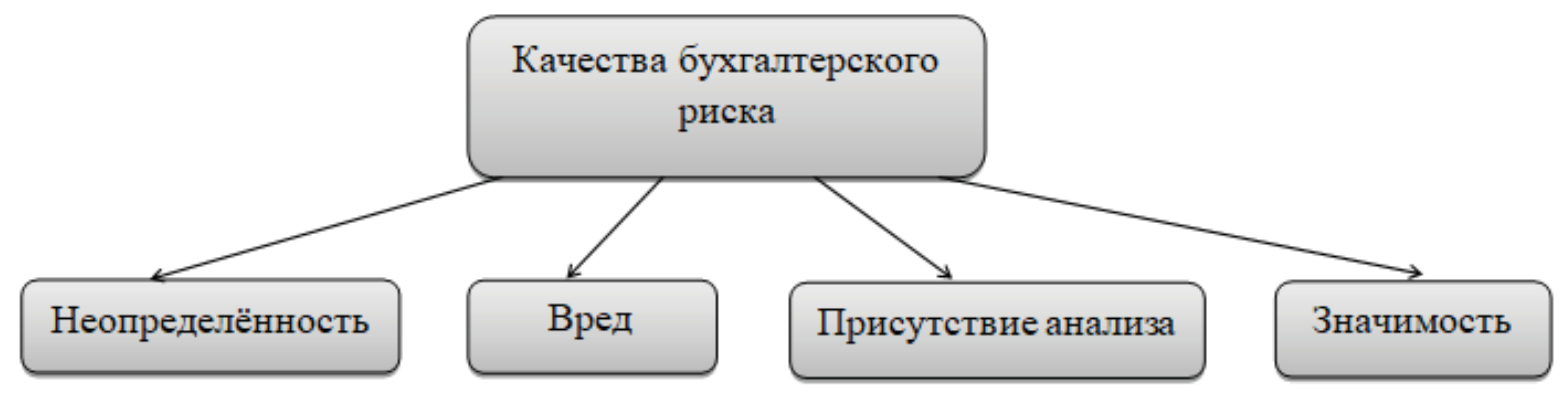

Рисунок 1. Качества бухгалтерского риска

Составление бухгалтерских данных и всякой информации о хозяйственной деятельности в целом подвержено неопределенности и связано с внешними факторами. Они воздействуют на все платные операции. Также с внутренними факторами, образующимися в системе бухгалтерского учета. И они воздействуют на формирование характеристик бухгалтерской отчетности, а также на управленческие решения.

Организация, осуществляя свою деятельность, оказывается в ситуации неопределенности, что чревато рисками в будущем, образовавшимися в процессе принятия не очень благоприятных решений внешними пользователями, которые обоснованы отсутствием информативной отчетности. Дабы убавить неопределенность, нужно усовершенствовать существующие нормативы в направлении формирования новой системы характеристик, которая бы правильно отвечала необходимостям рынка денежных средств.

Бухгалтерской финансовой отчетности характеризуется значительной степенью неопределенности, которая связана с ходом ее формирования и представления. Обеспечение полноты и достоверности информации, отражаемой в отчетности невозможно без выявления и оценки бухгалтерских рисков, как на этапе планирования, так и в текущей деятельности организации в целях принятия доказанных решений по их снижению. В этой связи вопросы, связанные с понятием бухгалтерских рисков и их чертой, в настоящее время обретают все большую актуальность.

Так, появление в бухгалтерском учете категории риска и необходимость предоставления информации о рисках обусловлены следующими основными показателями: 
1) стандарты бухгалтерского учета - они дают право выбора оценок, формата информации и отчетности, выбора показателей, наиболее достоверно отражающих итоги их деятельности и финансовое состояние, по мнению предпринимателей.

2) воздействие рынка денежных средств на формат и содержание финансовой отчетности.

Главные требования к достоверности финансовой отчетности изложены в статье 13 федерального закона № 402-Ф3 «О бухгалтерском учете».

Обепечение полноты и достоверности информации, отражаемой в отчетности невозможно без выявления и оценки бухгалтерских рисков, как на этапе планирования, так и в текущей деятельности организации в целях принятия обоснованных решений по их сокращению. В этой связи вопросы, которые связанны с понятием бухгалтерских рисков и их характеристикой, на сегодняшний день приобретают все большую актуальность.

Особенности риска, выявление причин его появления, позволит держать под контролем в организации механизм его минимизации и действенно управлять риском. Состав основных видов бухгалтерских рисков, прежде всего влияющих на составление финансовой отчетности, представлен на рис. 2.

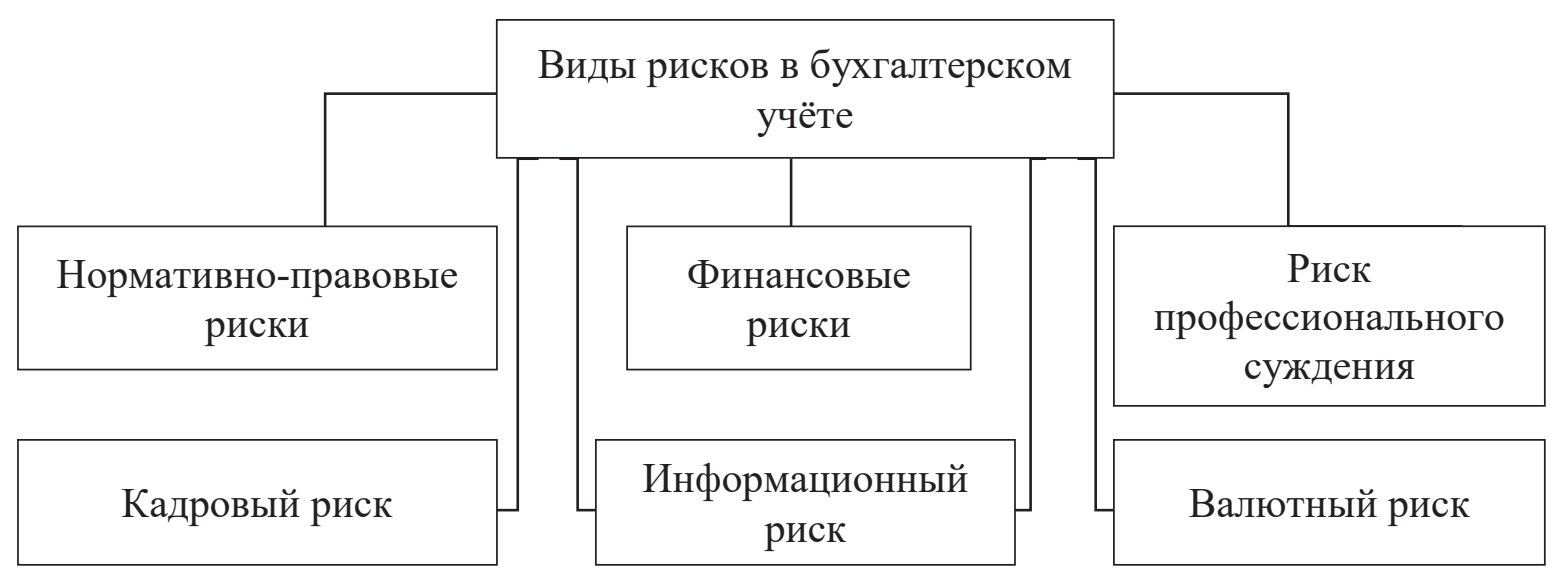

Рисунок 2. Виды бухгалтерских рисков

Среди бухгалтерских рисков, с нашей точки зрения, в первую очередь необходимо отметить риски, связанные с человеческим фактором, поскольку, несмотря на то, что финансовая отчетность формируется на базе положений, установленных нормативными правовыми актами, у бухгалтера остается широкий круг вопросов, по которым он вправе брать на себя принятие важных решения самостоятельно.

В системе бухгалтерских рисков особенное пространство занимают нормативноправовые риски. На данный момент действующие положения по бухгалтерскому учету Российской Федерации, к огорчению, обхватывают не все финансовые объекты, бухгалтерский учет которых регламентируется международными стандартами, содержат противоречия, разночтения, собственно, что в итоге приводит к риску допустить ошибки в их использовании в учетной практике организаций.

Следующий наиболее значимый вид бухгалтерского риска, влияющий на финансовую отчетность, как нам кажется, является финансовый риск, который в себя включает инфляционный и валютный. В критериях инфляции бухгалтерская отчетность не позволяет объективно оценить действительную стоимость фирмы, ее экономическое состояние и итоги деятельности. Незначительная степень инфляции не оказывает сильного влияния на отчетность, высокий - отображается на всех сторонах финансово-хозяйственной деятельности предприятия. Влияние инфляции заключается 
в том, что оценка статей баланса, например, внеоборотные активы, акции искусственно занижены по сравнению с их реальной стоимостью, а таких статей, как средства в расчетах, денежных средств увеличивается. Отказ в стоимости активов от их реальной оценки приводит в результате к изменению фактической издержки реализации, завышению прибыли и рентабельности.

Изменчивость решений в условиях выполнения определенной бухгалтерской задачи приводит к возникновению риска, который в международной практике именуется риском профессионального суждения. Это происходит в результате того, что международные стандарты устанавливают только общие принципы и требования к раскрытию информации, решение о выборе конкретных процедур оценки статей отчетности и формирования финансовой информации принимает бухгалтер.

Кадровый риск - это трудный риск, в составе которого можно отметить: должностной риск (несоответствие должности видам деятельности, целям, задачам, функциям и технологиям); квалификационно-образовательный (несоответствие сотрудника занимаемой должности); риск злоупотреблений и недобросовестности (зависит от уровня работы по подбору и найму персонала, от эффективности деятельности служб безопасности, результативности контрольно-ревизионного аппарата, от манеры управления, корпоративной культуры).

Информационный риск - это случайное событие, которое приводит к негативным последствиям в информационной системе. Влияя на информационную систему, риски приводят организацию к вреду и потерям. Информационный риск может быть вызван как внутренними, так и внешними причинами.

Валютный риск связан с риском лишения части прибыли при обмене, покупке, или продажи зарубежной валюты, курс которой располагается в неизменном перемещении, а также при отсрочке платежей во внешнеэкономических сделках.

Подводя итог всему вышесказанному, для снижения неопределенности в бухгалтерском учете, обеспечения достоверности бухгалтерской отчетности, как для предприятия, так и для внешних пользователей, необходимо создать комплекс мер, нацеленных на снижение бухгалтерских рисков, основанный, прежде всего, на глубоком и детальном их описании. Отчетная информация станет неопровержимой, если она основанная на единых методологических подходах, поставленных в международных стандартах отчетности, то она будет содержать пояснения и дополнения, раскрывающие информацию о рисках.

$$
* * *
$$

1. Федеральный закон от 06.12.2011 № 402-Ф3 «О бухгалтерском учете»

2. Об утверждении Положений по бухгалтерскому учету (вместе с Положением по бухгалтерскому учету «Учетная политика организации» (ПБУ 1/2008)», Положением по бухгалтерскому учету «Изменения оценочных значений» (ПБУ 21/2008)): утв. Приказом Минфина Рос. Федерации от 6 октября 2008 г. № 106н; в ред. Приказа Минфина Рос. Федерации от 06 апр. 2018 г. № 57н // Бюллетень нормативных актов федеральных органов исполнительной власти. - 2008. - № 44; Официальный интернет-портал правовой информации http:// www.pravo.gov.ru, 2020.

3. Аспекты оценки финансового состояния предприятия на основе показателей бухгалтерской (финансовой) отчетности в условиях мирового кризиса. Измалкова И.В. В сборнике: Управление социально-экономическим развитием регионов: проблемы и пути их решения. Сборник статей 10й Международной научно-практической конференции. 2020. С. 198-203.

4. Кудряшова В.В. Риски в бухгалтерском учёте. Вестник МГУП, М: МГУП, 2018.

5. Огильба, А. В. Характеристика основных видов бухгалтерских рисков / А. В. Огильба, О. В. Рура. — Текст : непосредственный // Молодой ученый. - 2017. — № 11.1 (115.1). — C. 38-41. — URL: https://moluch.ru/archive/115/30774/ 